\title{
Alkaline instant noodles: use of alkaline salts to reduce sodium and assessment of calcium bioaccessibility
}

Macarrão instantâneo alcalino: uso de sais alcalinos para redução de sódio e avaliação da

bioacessibilidade do cálcio

Fideos instantáneos alcalinos: uso de sales alcalinas para reducir el contenido sodio y evaluación de la bioaccesibilidad del calcio

\author{
Ana Paula Rebellato \\ ORCID: https://orcid.org/0000-0002-7308-5127 \\ State University of Campinas, Brazil \\ E-mail: paularebe@hotmail.com \\ Priscila Ferreira Tavares \\ ORCID: https://orcid.org/0000-0001-8570-9817 \\ State University of Campinas, Brazil \\ pritavares04@gmail.com \\ Guilherme Neves Trindade \\ ORCID: https://orcid.org/0000-0003-0487-0129 \\ State University of Campinas, Brazil \\ E-mail: guilherme.trindade@external.imerys.com \\ Juliana A. Lima Pallone \\ ORCID: https://orcid.org/0000-0002-8517-2922 \\ State University of Campinas, Brazil \\ jpallone@fea.unicamp.br \\ Pedro H. Campelo \\ ORCID: https://orcid.org/0000-0003-1538-7941 \\ Federal University of Amazonas, Brazil \\ E-mail: pedrocampelo@ufam.edu.br \\ Maria Teresa Pedrosa Silva Clerici \\ ORCID: https://orcid.org/0000-0002-8445-336X \\ State University of Campinas, Brazil \\ E-mail: mclerici@unicamp.br
}

\begin{abstract}
Instant noodles originated in eastern nations and have been accepted due to its practicality and low cost. However, its high sodium content can lead to health problems. The present study aimed to reduce sodium and increase calcium levels in noodles. A control $\left(\mathrm{N} 1: \mathrm{K}_{2} \mathrm{CO}_{3}+\mathrm{Na}_{2} \mathrm{CO}_{3}\right)$ and three treatments with the addition of calcium carbonate in combination with alkaline salts such as potassium and sodium carbonates $\left(\mathrm{N} 2: \mathrm{K}_{2} \mathrm{CO}_{3}+\mathrm{CaCO}_{3} ; \mathrm{N} 3: \mathrm{Na}_{2} \mathrm{CO}_{3}+\mathrm{CaCO}_{3}\right.$; and $\mathrm{N} 4$ : $\mathrm{CaCO}_{3}$ ) were studied. Two hydration methods were investigated, and the technological characterization and the calcium bioaccessibility of the different noodle formulations were determined. N4 did not fit into the alkaline noodle category due to its neutral $\mathrm{pH}$. N2 and N4 showed a sodium reduction of around $28 \%$ and a significant increase in calcium content, with higher bioaccessible calcium. Significant changes were observed for the noodles made with the addition of different alkaline salts, with a light-yellow color and better texture than the control, which can be a positive aspect, once products with reduced nutrients usually present differentiated coloring. Therefore, the use of calcium carbonate may be a promising alternative to increase $\mathrm{Ca}$ intake and to reduce the sodium content of instant noodles.
\end{abstract}

Keywords: Cereal product; Mineral bioaccessibility; In vitro digestion; Calcium; Sodium.

\section{Resumo}

O macarrão instantâneo é originário de países orientais e tem grande aceitação devido à sua praticidade e baixo custo. No entanto, seu alto teor de sódio pode causar problemas de saúde. O presente estudo teve como objetivo a redução do teor de sódio e aumento dos níveis de cálcio no produto. Um controle $\left(\mathrm{N} 1: \mathrm{K}_{2} \mathrm{CO}_{3}+\mathrm{Na}_{2} \mathrm{CO}_{3}\right)$ e três tratamentos com a adição de carbonato de cálcio em combinação com sais alcalinos, como carbonatos de potássio e sódio $\left(\mathrm{N}_{2}: \mathrm{K}_{2} \mathrm{CO}_{3}+\right.$ $\mathrm{CaCO}_{3} ; \mathrm{N} 3: \mathrm{Na}_{2} \mathrm{CO}_{3}+\mathrm{CaCO}_{3}$; e N4: $\mathrm{CaCO}_{3}$ ) foram estudados. Dois métodos de hidratação foram investigados e a caracterização tecnológica e a bioacessibilidade de cálcio das diferentes formulações de macarrão foram determinadas. O N4 não se encaixou na categoria de macarrão alcalino devido ao seu pH neutro. N2 e N4 apresentaram redução de sódio em torno de $28 \%$ e aumento significativo do teor de cálcio, com maior cálcio bioacessível. Mudanças significativas foram observadas para o macarrão feito com a adição de diferentes sais alcalinos, com cor amarelo claro 
e melhoria da textura em relação ao controle, o que pode ser um aspecto positivo, uma vez que produtos com nutrientes reduzidos costumam apresentar coloração diferenciada. Portanto, o uso de carbonato de cálcio pode ser uma alternativa promissora para aumentar a ingestão de Ca e reduzir o teor de sódio do macarrão instantâneo.

Palavras-chave: Produto à base de cereais; Bioacessibilidade de minerais; Digestão in vitro; Cálcio; Sódio.

\section{Resumen}

Originarios de las naciones orientales, los fideos instantáneos han sido aceptados debido a su practicidad y bajo costo. Sin embargo, su alto contenido en sodio puede provocar problemas de salud. El presente estudio tuvo como objetivo reducir el contenido de sodio y aumentar los niveles de calcio en los fideos. Para ello, se estudiaron una muestra control (N1: K2CO3 + Na2CO3) y tres tratamientos con adición de carbonato de calcio en combinación con sales alcalinas de carbonato de potasio y sodio $\left(\mathrm{N}_{2}: \mathrm{K}_{2} \mathrm{CO}_{3}+\mathrm{CaCO}_{3} ; \mathrm{N}_{3}: \mathrm{Na}_{2} \mathrm{CO}_{3}+\mathrm{CaCO}_{3} ;\right.$ y $\left.\mathrm{N} 4: \mathrm{CaCO}_{3}\right)$. Se investigaron dos métodos de hidratación, asimismo, se realizó la caracterización tecnológica y se determinó la bioaccesibilidad del calcio de las diferentes formulaciones de fideos. N4 no encajó en la categoría de fideos alcalinos debido a su pH neutro. N2 y N4 experimentaron una reducción alrededor del $28 \%$ de sodio y un aumento significativo del contenido y bioaccesibilidad de calcio. Se observaron cambios significativos en los fideos elaborados con la adición de las diferentes sales alcalinas, como un color amarillo claro y mejor textura en comparación al control, lo que puede ser un aspecto positivo dado que los productos con reducción nutrientes suelen presentar una coloración diferenciada. Por tanto, el uso de carbonato de calcio puede ser una alternativa prometedora para aumentar la ingesta de $\mathrm{Ca}$ y reducir el contenido de sodio en fideos instantáneos.

Palabras clave: Producto de cereales; Bioaccesibilidad mineral; Digestión in vitro; Calcio; Sodio.

\section{Introduction}

People with chronic non-communicable diseases are at high risk of severe Covid-19, including hypertension and heart disease (Hobbs, 2020; Hoover, 2020). Thus, sodium reduction is required in easy-to-make foods, especially those packaged for single-use, once the quarantine led to an increase in the food-at-home consumption of these products (Hoover, 2020). In this context, instant noodles have stood out, which have shown an increased demand in the Brazilian market, with consumption of $0.129 \mathrm{~kg} /$ inhabitant in 2019 (Abimapi, 2020).

It is believed that instant noodles originated in China in 5000 B.C. However, the first instant noodles were made in Japan in 1958, and have become widely consumed by the eastern and western populations (Fu, 2008; Han et al., 2012). According to the World Instant Noodles Association (Wina, 2020), the world's largest consumer of noodles is China/Hong Kong, with a record intake of 41.45 million servings in 2019, followed by Indonesia with 12.52 million servings. The main reasons for widespread popularization include practicality, long shelf-life, and low cost (Fu, 2008; Gulia et al., 2014). However, they are considered products with high fat and sodium contents, which do not meet the current guidelines for healthy eating.

Instant noodles are mainly made from wheat flour, starch, water, salt, or kansui (a mixture of sodium and potassium carbonates and phosphates) and other ingredients to improve texture, color, and flavor (Gulia et al., 2014; Kruger et al., 1996).In general, the manufacturing process of noodles includes lamination and cutting, followed by cooking and frying (Fu, 2008).The final product should contain 15 to $20 \%$ fat, which can lead to greater susceptibility to lipid oxidation of the product during the storage (Gulia et al., 2014). Studies have suggested the use of different drying methods, such as microwave radiation, infrared, and hot air, to produce noodles with reduced fat content (Ismailoglu \& Basman, 2016; Pongpichaiudom \& Songsermpong, 2018; Wang et al., 2011).

Sodium is considered an essential element for human life and has relevant technological and sensory functions in food products (Orlando et al., 2020). However, its excessive consumption is associated with the development of chronic diseases, such as hypertension, cardiovascular, and kidney diseases, among others (Nilson et al., 2012). The consumption of instant noodles provides more than $700 \mathrm{mg}$ of sodium per serving, which corresponds to approximately $29 \%$ of the recommended daily intake. Therefore, studies on salt-reduced noodles are necessary, aiming to reduce the risk of developing diseases related to high sodium intake (Gropper et al., 2011; Park et al., 2011).

In this context, the replacement of sodium for calcium in noodles can be an interesting alternative since calcium is an 
essential mineral for the functioning of the human body. Its function is closely associated with the construction and maintenance of bones and teeth, while its deficiency can cause osteoporosis, and long-term deficiency can lead to hypertension, colon cancer, and obesity (Gropper et al., 2011).

Some authors have studied the replacement of sodium by calcium carbonate in different food matrices such as bread, coffee, and soy beverages, among others, as calcium carbonate is an inexpensive and available source of calcium (Gulia et al., 2014; Kajishima et al., 2003; Paula, 2013; Umbelino et al., 2001). However, studies on the use of calcium carbonate in instant noodles and the calcium bioaccessibility have not been found in the literature.

Mineral bioaccessibility has been investigated in different food matrices, as it can estimate, through in vitro tests, the availability of an element of interest to be absorbed by the human body (Cámara et al., 2005; Miller et al., 1981; Rebellato et al., 2015; Sahuquillo et al., 2003; Silva et al., 2020). The in vitro dialysis assay allows evaluating the transport of nutrients through the use of a semipermeable membrane with defined pore sizes, similar to the intestinal pores. The method also allows determining the time required for the material to move through the gastric and intestinal phases, with changes in pH, agitation, and temperature to simulate the human body (Alegría-Torán et al., 2015; Miller et al., 1981; Perales et al., 2006).

Thus, in the present study, instant noodles were made with the addition of calcium carbonate and different combinations of alkaline salts, such as potassium and sodium carbonates, aiming at reducing sodium and increasing calcium in the formulations. The technological characterization and the evaluation of calcium bioaccessibility in the different formulations were also performed.

\section{Methodology}

\subsection{Materials}

For the production of alkaline instant noodles, wheat flour type 1 enriched with iron and folic acid was donated by Pastificio Selmi (Sumaré, São Paulo), vegetable fat, potassium carbonate, and sodium carbonate were purchased in the local market, and calcium carbonate (I-Blum F22) was donated by Imerys do Brasil.

For calcium quantification, the following reagents were used: nitric acid, and hydrogen peroxide (Sigma-Aldrich, USA; Merck, Germany); calcium standard solution $1000 \mathrm{mg} / \mathrm{Kg}$ (Qhemis, Jundiaí, Brazil); purified water; and black ribbon quantitative filter paper. For the bioaccessibility assay, pepsin (P-7000), pancreatin P-7545, bile salts extract (B-8631), and cutoff dialysis membranes (12,000 Da and $25 \AA$ ) were purchased from Sigma Chemical Co. (St Louis, MO, USA),

The mineralized samples were evaluated by flame atomic absorption spectrometer (FAAS), model AAnalyst 200 (PerkinElmer). For the evaluation of calcium mineral, the equipment was operated in absorption mode, with hollow cathode lamps (422.67 nm). Each sample was placed into the nebulizer and mixed with air-acetylene flame $(2.5 / 10 \mathrm{~L} / \mathrm{h})$ at approximately $2000^{\circ} \mathrm{C}$.

\subsection{Methods}

\subsubsection{Manufacture of instant noodles with different combinations of alkaline salts}

The wheat flour was submitted to a mixing stage (mixer KitchenAid - Professional) and after 2 minutes, water and previously dissolved salts were added, with homogenization for another 13 minutes until forming a homogeneous mixture. Then, the mixture remained at rest for 10 minutes, followed by lamination in an automatic cylinder (Pastaia 2, BRALYX, Poleto, and Partners), with a gradual reduction of the spacing between the cylinders until reaching $1.2 \mathrm{~mm}$ thickness. The dough was cut 0.9 $\mathrm{mm}$ wide in the same equipment and portioned at $25 \pm 0.50 \mathrm{~g}$ for cooking in a steam oven at $120{ }^{\circ} \mathrm{C}$ for 3 minutes (PRÁTICA, Technipan). Then, the dough was oven-baked $\left(25 \pm 1^{\circ} \mathrm{C}\right)$ for 1 hour and 30 minutes, and deep-fat fried at $130{ }^{\circ} \mathrm{C}$ for 30 seconds (Sina, Vegetal Fry 32). The noodle was exposed to ventilation for 10 minutes, packed in plastic packages, and stored at a 
controlled temperature in absence of light. Four noodle formulations were made, using $1.5 \% \mathrm{NaCl}, 1 \%$ alkaline salts, and $38 \%$ water, calculated based on the amount of wheat flour (100\%) and different sodium carbonate concentrations, as follows: control $\mathrm{N} 1$ containing $0.50 \% \mathrm{~K}_{2} \mathrm{CO}_{3}+0.50 \% \mathrm{Na}_{2} \mathrm{CO} 3$; formulation $\mathrm{N} 2$ containing $0.50 \% \mathrm{~K}_{2} \mathrm{CO}_{3}+0.50 \% \mathrm{CaCO}_{3}$; formulation $\mathrm{N} 3$ containing $0.50 \% \mathrm{Na}_{2} \mathrm{CO}_{3}+0.50 \% \mathrm{CaCO}_{3}$; and formulation $\mathrm{N} 4$ containing $1 \% \mathrm{CaCO}_{3}$.

\subsubsection{Technological characterization of instant noodles with different combinations of alkaline salts}

The moisture content was determined according to the method 44-15.02 of AACCI (2010); fat content was calculated through the mass balance, considering the moisture values before and after frying; water activity (aw) was measured in a 4 TEV Aqualab apparatus (Decagon Devices, Inc., Pullman, Washington, USA), solid loss was determined according to the method 1650 of AACC (2000), with modifications by Gull et al. (2015); the nutritional composition was estimated according to the nutritional composition of the ingredients; and $\mathrm{pH}$ was determined according to the Analytical Standards of the Adolfo Lutz Institute (IAL, 2008).

\subsubsection{Color measurements}

The color parameters $\mathrm{L}^{*}, \mathrm{a}^{*}$, and $\mathrm{b}^{*}$ were determined using a MiniScan XE portable colorimeter (Hunter Associates Laboratory, Inc., Reston, Virginia, USA), with D65 illuminant, and $10^{\circ}$ observation angle.

\subsubsection{Texture profile analysis}

The texture profile of fried noodles and hydrated noodles was analyzed according to the method 66-50 of AACC (1999), with the aid of the TA-XT2 texture analyzer, with a load of $50 \mathrm{~kg}$ (Stable Micro Systems, Surrey, England). The force and compression parameters were determined, using pre-test speed $=0.50 \mathrm{~mm} / \mathrm{s}$, test speed $=1.70 \mathrm{~mm} / \mathrm{s}$, post-test speed $=10.00$ $\mathrm{mm} / \mathrm{s}$, and distance $=40 \%$.

\subsubsection{Calcium bioaccessibility of instant noodles with different combinations of alkaline salts}

To quantify the calcium content, $80.37 \pm 0.53 \mathrm{~g}$ of sample was cooked in $450 \mathrm{~mL}$ of boiling water for 3 minutes. The samples were transferred to glass containers and cooled to room temperature. Then, aliquots of $10 \mathrm{~mL}$ of the cooking water were used to determine the soluble calcium content during cooking. The remaining mixture (water and noodle) was homogenized in a food processor to determine the calcium content.

The quantification of total and dialysate calcium was performed as described by Rebellato et al. (2015). For that, 0.60 $\mathrm{g}$ of sample was placed indigestion tubes and $8 \mathrm{~mL}$ of nitric acid and $2 \mathrm{~mL}$ of hydrogen peroxide was added and subjected to digestion in a block digester for 2 hours at $110^{\circ} \mathrm{C}$. Subsequently, the tubes were sonicated, the contents transferred to a $25 \mathrm{~mL}$ volumetric flask, and filtered. The quantification was performed by flame atomic absorption spectrometry.

The dialysis assay was performed as described by Rebellato et al. (2015), with modifications. For that, $5 \mathrm{~g}$ of sample was homogenized with $30 \mathrm{~mL}$ of ultra-pure water, and the $\mathrm{pH}$ was adjusted to $2.00 \mathrm{using} 6 \mathrm{~mol} / \mathrm{L} \mathrm{HCl}$. The gastric stage initiated with the addition of $0.65 \mathrm{~mL}$ of pepsin solution in $0.10 \mathrm{~mol} / \mathrm{L} \mathrm{HCl}$, and incubation in a metabolic bath at $37^{\circ} \mathrm{C}$ for $2 \mathrm{~h}$.

At the end of the gastric stage, the sample was removed from the metabolic bath and placed in an ice bath for 10 minutes. Then, $6.50 \mathrm{~mL}$ of the pancreatin-bile mixture solubilized in $0.10 \mathrm{~mol} / \mathrm{L} \mathrm{NaHCO} 3$ was added to the digest, followed by titration using $0.50 \mathrm{~mol} / \mathrm{L} \mathrm{NaOH}$ until pH 7.20. After knowing the molar equivalent in $0.50 \mathrm{~mol} / \mathrm{L} \mathrm{NaHCO}$, the dialysis membranes were filled with $0.50 \mathrm{~mol} / \mathrm{L} \mathrm{NaHCO} 3$ and the volume was filled with ultra-pure water $(30 \mathrm{~mL})$. The membranes were placed in the flasks containing the digest and incubated for 30 minutes. Then, $6.50 \mathrm{~mL}$ of the pancreatin-bile mixture was added to the flasks and incubated for a further $2 \mathrm{~h}$ at $37^{\circ} \mathrm{C}$. After incubation, the membranes were removed from the flasks, washed with 
ultra-pure water, and the dialysate was transferred to digestion tubes and incubated in an oven at $100{ }^{\circ} \mathrm{C}$ for $24 \mathrm{~h}$. After the volume reduction, the samples were digested in an acid medium $(8 \mathrm{~mL}$ of nitric acid and $2 \mathrm{~mL}$ of hydrogen peroxide), in a digester block for $2 \mathrm{~h}$ at $110^{\circ} \mathrm{C}$. Subsequently, calcium was quantified by atomic absorption. The determinations were performed in four repetitions.

\subsubsection{Statistical analysis}

All analysis were performed in triplicate, except for the bioaccessibility assay, which was performed in four replications. The results were expressed as mean \pm deviation. The means were evaluated by the Scott-Knott test, using the SISVAR software (version 5.6 - Build 86) and t-Student test, using the XLSTAT software (version 2018.2.50634).

\section{Results and Discussion}

\subsection{Manufacture of instant noodles with different combinations of alkaline salts}

During manufacture, the noddle formulations N2 to N4 containing calcium carbonate showed better machinability, when compared to the control (N1), which facilitated the lamination step. This result may be due to a strengthening of the gluten network since calcium carbonate can also act as a dough conditioner (Smith \& Hong-Shum, 2011).

After the manufacture of the noodles, a color difference was observed for the formulations N2 to N4, which exhibited a lighter yellow color when compared with the formulation N1, probably due to different $\mathrm{pH}$ values. The lighter color of calciumcontaining noodles can be a positive aspect, as products with reduced nutrients present light color, as a way to show the rapid changes to consumers. Regarding the integrity of the pasta threads, no differences were observed between the formulations.

\subsection{Technological characterization of instant noodles with different combinations of alkaline salts}

The parameters evaluated in the technological characterization are shown in Table 1. The moisture content is an important parameter, not only for microbiological control but also as an indicator of quality (Yu \& Ngadi, 2004). Although the results of fried noodles were in accordance with the Brazilian legislation, which has established moisture contents lower than 10\% for instantaneous pasta (Brasil, Ministério da Agricultura, 2000), the formulations N3 and N4 showed a higher moisture content and differed significantly from N1 and N2. This result demonstrates that calcium carbonate, when used alone or in combination with other alkaline salts $\left(\mathrm{Na}_{2} \mathrm{CO} 3\right)$, contributed to greater water retention in the final product, probably due to the anti-humectant capacity of calcium carbonate (Brazil, 2010).

The fat content was calculated by mass balance, through the difference between the moisture values before and after frying, once the water molecules form channels allowing the passage of fat into the product (Hou, 2001). Before frying or just after the steaming stage, the moisture content of the noodle formulations varied from $15.53 \%$ to $18.47 \%$. Right after the frying step, the moisture content varied from $6.09 \%$ to $7.82 \%$, and the fat content ranged from $9.18 \%$ to $10.64 \%$, with no significant differences between the samples.

Regarding the water activity (aw), the values were close to those reported in the literature, which establishes values close to 0.50 for fried alkaline instant noodles (Hou, 2010). Although the formulations N3 and N4 had the highest moisture values, they presented the lowest aw values when compared to the control. No significant differences were observed for the moisture content of the formulation N2 when compared with the control; however, it presented lower aw than N1, that is, the water retained by calcium carbonate was not free for microbiological growth, thus with no impact on the shelf life of the product. 
Table 1. Technological characteristics of alkaline instant noodle with different combinations of alkaline salts ${ }^{1}$

\begin{tabular}{|c|c|c|c|c|c|}
\hline Samples & Parameters & N1 & $\mathbf{N 2}$ & $\mathbf{N 3}$ & N4 \\
\hline \multirow{4}{*}{$\begin{array}{l}\text { Fried alkaline } \\
\text { instant noodle }\end{array}$} & Moisture (\%) & $6.09 \pm 0.48^{b}$ & $6.41 \pm 0.16^{\mathrm{b}}$ & $7.27 \pm 0.18^{\mathrm{a}}$ & $7.82 \pm 0.39^{\mathrm{a}}$ \\
\hline & $\begin{array}{c}\text { Theoretical percentage of fat } \\
(\%)\end{array}$ & $9.43 \pm 1.89^{\text {n.s. }}$ & $9.18 \pm 1.90^{\text {n.s. }}$ & $9.54 \pm 1.47^{\text {n.s. }}$ & $10.64 \pm 1.71^{\text {n.s. }}$ \\
\hline & Water activity $\left(\mathrm{a}_{\mathrm{w}}\right)$ & $0.61 \pm 0.00^{\mathrm{a}}$ & $0.55 \pm 0.00^{c}$ & $0.56 \pm 0.00^{b}$ & $0.56 \pm 0.00^{\mathrm{b}}$ \\
\hline & $\mathrm{pH}$ & $10.37 \pm 0.27^{\mathrm{a}}$ & $9.30 \pm 0.11^{\mathrm{c}}$ & $9.59 \pm 0.01^{\mathrm{b}}$ & $7.45 \pm 0.02^{\mathrm{d}}$ \\
\hline \multirow{2}{*}{$\begin{array}{l}\text { Hydrated alkaline } \\
\text { instant noodle }\end{array}$} & $\begin{array}{c}\text { Solid loss }(\mathrm{g} / 100 \mathrm{~g}) \\
\text { conventional method }\end{array}$ & $6.24 \pm 0.00^{\text {n.s. }}$ & $7.42 \pm 0.24^{\text {n.s. }}$ & $6.35 \pm 1.21^{\text {n.s. }}$ & $7.27 \pm 0.19^{\text {n.s. }}$ \\
\hline & Solid loss $(\mathrm{g} / 100 \mathrm{~g})$ microwaves & $2.20 \pm 0.29^{\text {n.s. }}$ & $3.16 \pm 0.17^{\text {n.s. }}$ & $2.24 \pm 0.33^{\text {n.s. }}$ & $3.59 \pm 0.62^{\text {n.s. }}$ \\
\hline
\end{tabular}

${ }^{1}$ Results are presented as mean \pm standard deviations. $\mathrm{N} 1: 0.50 \% \mathrm{~K}_{2} \mathrm{CO}_{3}: 0.50 \% \mathrm{Na}_{2} \mathrm{CO}_{3} ; \mathrm{N} 2: 0.50 \% \mathrm{~K}_{2} \mathrm{CO}_{3}: 0.50 \% \mathrm{CaCO}_{3} ; \mathrm{N}_{3}: 0.50 \% \mathrm{Na}_{2} \mathrm{CO}_{3}: 0.50 \% \mathrm{CaCO}_{3}$; $\mathrm{N} 4: 1 \% \mathrm{CaCO}_{3}$. Means followed by different letters on the same line differ significantly from each other by the Scott-Knott test ( $\left.\mathrm{p}<0.05\right)$. Means followed by * in the same column differ significantly by Student's t-test ( $\mathrm{p}$-value $<0.05$ ) between Solid loss of alkaline instant noodle hydrated by conventional method and microwaves; n.s.: not significant.

Source: Authors.

Concerning solid loss during cooking, the noodles hydrated by microwave radiation showed the lowest values when compared to those hydrated by the conventional method. Although the solid loss may be lower than $10 \%$ for starch noodles, small losses are desirable (Tan et al., 2009). In addition, the solid loss is a consequence of several process parameters, such as mixing time, dough thickness, cooking temperature, and frying conditions (Gulia \& Khatkar, 2013). However, these parameters were fixed in this study to prevent possible interferences.

Table 2 shows the estimated nutritional composition, with emphasis on the sodium and calcium contents. The formulations N2 and N4 showed a reduction in the sodium content of $28 \%$ and $30 \%$, respectively, when compared with N1. In turn, the formulations $\mathrm{N} 2, \mathrm{~N} 3$, and N4 showed an increase in calcium content, positively impacting the recommended daily intake by $10 \%, 9 \%$, and $19 \%$, respectively.

Studies have shown that the consumption of instant noodles is directly associated with higher sodium intakes (Park et al., 2011) and consequently, an increase in the development of chronic non-communicable diseases, such as heart attack and stroke. Therefore, the use of a combination of salts, such as the present study, or the partial replacement of sodium by calcium carbonate can be an interesting alternative for the instant noodles industries, which can partially replace sodium for another salt with less negative health impacts.

Concerning the $\mathrm{pH}$ values, the formulations N1 to N3 showed alkaline $\mathrm{pH}$, while N4 had neutral pH, thus classified as a common noodle rather than alkaline noodle. The $\mathrm{pH}$ range for alkaline noodles should remain from pH 9 to 11 (Hou, 2001 ). The $\mathrm{pH}$ is directly related to the color of the product, due to the presence of flavonoid compounds in wheat flour, exhibiting yellow color in an alkaline environment, which increases with increasing the $\mathrm{pH}$ values (Hou, 2001).

\subsection{Color measurements in instant noodles with different combinations of alkaline salts}

The luminosity $\left(\mathrm{L}^{*}\right)$ and chromaticity $\left(\mathrm{a}^{*}\right.$ and $\left.\mathrm{b}^{*}\right)$ parameters were determined to assess the color of the different noodle formulations, as shown in Table 3. No significant differences in luminosity were observed for the fried formulations N1, N2, and N3, whereas the formulation N4 presented the highest luminosity and differed from the other formulations. Similar behavior was observed for the formulations hydrated by both conventional and microwave methods. Concerning the parameter $\mathrm{a}^{*}$, which corresponds to red (+ a) and green (-a), the formulations N1 and N4 showed more reddish color when compared with N2 and N3. After hydration by the conventional and microwave methods, an increase in a* values were observed for the formulations $\mathrm{N} 1$, N2, and N3, while a decrease of this coordinate was observed for N4 when compared to the fried noodles. Regarding the parameter b*, which is related to yellow (+b) and blue (-b), the fried noodles showed a reduction in yellow color from N1 to N4, 
which was also observed for samples hydrated by microwaves. For the conventional hydration method, only the formulation N4 showed a reduction in yellow color, with no differences between the other formulations.

Table 2. Estimated nutritional composition of alkaline instant noodle with different combinations of alkaline salts ${ }^{1}$

\begin{tabular}{|c|c|c|c|c|c|c|c|c|}
\hline \multirow[b]{2}{*}{ Parameters } & \multicolumn{2}{|c|}{ N1 } & \multicolumn{2}{|c|}{$\mathbf{N 2}$} & \multicolumn{2}{|c|}{ N3 } & \multicolumn{2}{|c|}{ N4 } \\
\hline & $\begin{array}{l}\text { Amount } \\
\text { per } \\
\text { serving } \\
(80 g)\end{array}$ & DV $(\%)$ & $\begin{array}{l}\text { Amount } \\
\text { per } \\
\text { serving } \\
(\mathbf{8 0 g})\end{array}$ & DV $(\%)$ & $\begin{array}{c}\text { Amount } \\
\text { per } \\
\text { serving } \\
(80 g)\end{array}$ & DV $(\%)$ & $\begin{array}{l}\text { Amount } \\
\text { per } \\
\text { serving } \\
(80 \mathrm{~g})\end{array}$ & DV (\%) \\
\hline Calories (kcal) & 212.39 & 11 & 209.19 & 10 & 214.04 & 11 & 209.67 & 10 \\
\hline Carbohydrate (g) & 37.63 & 13 & 37.27 & 12 & 37.84 & 13 & 36.23 & 12 \\
\hline Protein $(\mathrm{g})$ & 4.95 & 7 & 4.90 & 7 & 4.98 & 7 & 4.77 & 6 \\
\hline Total fat (g) & 4.67 & 8 & 4.50 & 8 & 4.75 & 9 & 5.07 & 9 \\
\hline Saturated fat (g) & 1.07 & 5 & 1.04 & 5 & 1.09 & 5 & 1.17 & 5 \\
\hline Unsaturated fat (g) & 3.60 & $* *$ & 3.47 & $* *$ & 3.66 & $* *$ & 3.91 & $* *$ \\
\hline Dietary fiber (g) & 0.99 & 4 & 0.98 & 4 & 1.00 & 4 & 0.95 & 4 \\
\hline Sodium (mg) & 399.37 & 17 & 289.07 & 12 & 401.54 & 17 & 281.03 & 12 \\
\hline Iron (mg) & 2.08 & 15 & 2.06 & 15 & 2.09 & 15 & 2.00 & 14 \\
\hline Calcium (mg) & 0.00 & 0 & 98.07 & 10 & 94.46 & 9 & 190.69 & 19 \\
\hline Folic acid $(\mu \mathrm{g})$ & 74.28 & 19 & 73.56 & 18 & 74.68 & 19 & 71.51 & 18 \\
\hline
\end{tabular}

${ }^{1} \mathrm{~N} 1: 0.50 \% \mathrm{~K}_{2} \mathrm{CO}_{3}: 0.50 \% \mathrm{Na}_{2} \mathrm{CO}_{3} ; \mathrm{N} 2: 0.50 \% \mathrm{~K}_{2} \mathrm{CO}_{3}: 0.50 \% \mathrm{CaCO}_{3} ; \mathrm{N} 3: 0.50 \% \mathrm{Na}_{2} \mathrm{CO}_{3}: 0.50 \% \mathrm{CaCO}_{3} ; \mathrm{N} 4: 1 \% \mathrm{CaCO} ; \mathrm{DV}_{2} \%$ Daily Values are based on a $2000 \mathrm{kcal}$ or $8400 \mathrm{~kJ}$. ** not established.

Source: Authors.

Table 3. CIE Lab L*, $a^{*}$, and $b^{*}$ values of fried and hydrated alkaline instant noodle with different combinations of alkaline salts ${ }^{1}$

\begin{tabular}{cccccc}
\hline Samples & Parameters & N1 & N2 & N3 & N4 \\
\hline \multirow{2}{*}{ Fried } & $\mathrm{L}^{*}$ & $57.42^{\mathrm{b}} \pm 3.55$ & $60.39^{\mathrm{b}} \pm 1.37$ & $59.22^{\mathrm{b}} \pm 2.32$ & $65.87^{\mathrm{a}} \pm 1.36$ \\
& $\mathrm{a}^{*}$ & $2.27^{\mathrm{a}} \pm 0.96$ & $0.41^{\mathrm{b}} \pm 0.05$ & $0.70^{\mathrm{b}} \pm 0.53$ & $1.91^{\mathrm{a}} \pm 0.05$ \\
& $\mathrm{~b}^{*}$ & $32.44^{\mathrm{a}} \pm 1.40$ & $27.10^{\mathrm{b}} \pm 0.40$ & $28.77^{\mathrm{b}} \pm 1.55$ & $20.14^{\mathrm{c}} \pm 0.80$ \\
\hline Hydrated by & $\mathrm{L}^{*}$ & $61.25^{\mathrm{c}} \pm 1.97$ & $68.15^{\mathrm{b}} \pm 2.07$ & $66.88^{\mathrm{b}} \pm 1.46$ & $76.05^{\mathrm{a}} \pm 0.28$ \\
conventional & $\mathrm{a}^{*}$ & $5.21^{\mathrm{a}} \pm 1.21$ & $1.15^{\mathrm{b}} \pm 0.53$ & $1.64^{\mathrm{b}} \pm 0.27$ & $0.99^{\mathrm{b}} \pm 0.14$ \\
method & $\mathrm{b}^{*}$ & $32.11^{\mathrm{a}} \pm 0.65$ & $29.62^{\mathrm{a}} \pm 0.91$ & $30.31^{\mathrm{a}} \pm 1.75$ & $18.92^{\mathrm{b}} \pm 0.90$ \\
\hline \multirow{2}{*}{ Hydrated by } & $\mathrm{L}^{*}$ & $61.35^{\mathrm{c}} \pm 0.24$ & $70.68^{\mathrm{b}} \pm 2.50$ & $69.85^{\mathrm{b}} \pm 0.93$ & $77.11^{\mathrm{a}} \pm 0.54$ \\
microwaves & $\mathrm{a}^{*}$ & $4.41^{\mathrm{a}} \pm 0.45$ & $1.45^{\mathrm{c}} \pm 0.23$ & $2.14^{\mathrm{b}} \pm 0.44$ & $1.43^{\mathrm{c}} \pm 0.06$ \\
& $\mathrm{~b}^{*}$ & $29.83^{\mathrm{a}} \pm 1.38$ & $26.51^{\mathrm{b}} \pm 0.97$ & $27.99^{\mathrm{b}} \pm 0.75$ & $19.28^{\mathrm{c}} \pm 0.14$ \\
\hline
\end{tabular}

${ }^{1}$ Results are presented as mean \pm standard deviations. $\mathrm{N} 1: 0.50 \% \mathrm{~K}_{2} \mathrm{CO}_{3}+0.50 \% \mathrm{Na}_{2} \mathrm{CO}_{3} ; \mathrm{N} 2: 0.50 \% \mathrm{~K}_{2} \mathrm{CO}_{3}+0.50 \% \mathrm{CaCO}_{3} ; \mathrm{N}_{3}: 0.50 \%$ $\mathrm{Na}_{2} \mathrm{CO}_{3}+0.50 \% \mathrm{CaCO}_{3} ; \mathrm{N} 4: 1 \% \mathrm{CaCO}_{3}$. Means followed by different letters on the same line differ significantly from each other by the Scott-Knott test (p-value $<0.05)$.

Source: Authors.

The presence of flavonoid compounds in wheat flour is not the only factor that can interfere with the color intensity of the final product, which can be affected by other factors including the grinding degree, the levels of starch, and the protein content of wheat flour (Asenstorfer et al., 2006; Baik\&Czuchajowska, 1995; Ye et al., 2009). Therefore, the addition of natural dyes, such as $\beta$-carotene, is a common practice in the production of commercial noodles as only the characteristics of the flour is not sufficient to achieve the desired color intensity. Thus, the light-yellow color of N4 can be prevented with process adjustments. 


\subsection{Texture profile of instant noodles with different combinations of alkaline salts}

As can be seen in Table 4, no significant differences were observed for the firmness values between the fried noodles. Regarding the formulations subjected to hydration by the conventional method, loss of firmness was reduced for N2 to N4 when compared to the control (N1). For the treatments hydrated by microwaves, a significant difference in firmness was observed for N3 and N4 when compared to the control. Interestingly, the formulation N4, made with the addition of sodium carbonate, was less firm or softer than the other formulations, probably due to the anti-humectant characteristic of calcium carbonate. It is worth mentioning that texture is a subjective parameter, as it depends on consumers' preference, which can vary from one country to another (Hou, 2001).

Table 4. Texture parameters of fried and hydrated alkaline instant noodle with different combinations of alkaline salts ${ }^{1}$

\begin{tabular}{|c|c|c|c|c|}
\hline Parameters & N1 & $\mathbf{N 2}$ & $\mathbf{N 3}$ & N4 \\
\hline Fried & $63.56 \pm 8.17^{\text {n.s. }}$ & $48.31 \pm 19.56^{\text {n.s. }}$ & $41.88 \pm 5.21^{\text {n.s. }}$ & $54.54 \pm 16.90^{\text {n.s. }}$ \\
\hline $\begin{array}{c}\text { Hydrated by } \\
\text { conventional method }\end{array}$ & $1.37 \pm 0.10^{\mathrm{a}}$ & $1.25 \pm 0.16^{\mathrm{b}}$ & $1.10 \pm 0.12^{\mathrm{c}}$ & $0.79 \pm 0.05^{\mathrm{d}}$ \\
\hline Hydrated by microwaves & $1.67 \pm 0.24^{\mathrm{a}}$ & $1.53 \pm 0.19^{a}$ & $1.32 \pm 0.12^{\mathrm{b}}$ & $0.89 \pm 0.16^{\mathrm{c}^{*}}$ \\
\hline $\begin{array}{l}\text { Time until the fried samples reached } \\
\text { the maximum firmness (s) }\end{array}$ & $4.26 \pm 1.47^{\mathrm{b}}$ & $6.07 \pm 0.95^{\mathrm{a}}$ & $4.94 \pm 1.82^{\mathrm{b}}$ & $6.03 \pm 1.09^{\mathrm{a}}$ \\
\hline
\end{tabular}

${ }^{1}$ Results are presented as mean \pm standard deviations. $\mathrm{N} 1: 0.50 \% \quad \mathrm{~K}_{2} \mathrm{CO}_{3}+0.50 \% \mathrm{Na}_{2} \mathrm{CO}_{3} ; \mathrm{N} 2: 0.50 \% \mathrm{~K}_{2} \mathrm{CO}_{3}+0.50 \% \mathrm{CaCO}_{3} ; \mathrm{N}_{3}: 0.50 \%$ $\mathrm{Na}_{2} \mathrm{CO}_{3}+0.50 \% \mathrm{CaCO}_{3} ; \mathrm{N} 4: 1 \% \mathrm{CaCO}_{3}$. Means followed by different letters on the same line differ significantly from each other by the ScottKnott test ( $p$-value $<0.05$ ). Means followed by * in the same column differ significantly by Student's t-test $(p<0.05)$ between the noodle hydrated by conventional method and microwaves. Source: Authors.

Concerning the fried noodles, the time to reach the maximum firmness was also evaluated, which was calculated through graphs generated during the analysis. The formulations $\mathrm{N} 1$ and $\mathrm{N} 3$, which contained $\mathrm{Na}_{2} \mathrm{CO}_{3}$, reached the maximum firmness within four seconds, while the formulations $\mathrm{N} 2$ and $\mathrm{N} 4$ with the addition of $\mathrm{CaCO}_{3}$ required a longer time to reach maximum firmness. The addition of calcium carbonate in the formulations N1 and N3 provided greater resistance to breakage, suggesting that its use may reduce breakage during processing, which is one of the main challenges of the instant noodle industry.

\subsection{Calcium bioaccessibility of instant noodles with different combinations of alkaline salts}

Before performing the bioaccessibility assay, all noodle formulations were cooked, according to Section 2.2.5, and the calcium (Ca) content in the cooking water was determined. The Ca levels varied from 0.35 to $4.01 \mathrm{mg} / 100 \mathrm{~g}$, with the higher and the lower loss of calcium during cooking observed for the control (N1) and the formulation N2, with values of $13 \%$ and $0.64 \%$, respectively (Table 5). The calcium content of the cooking water is dependent on the salt used in the formulations. However, as instant noodles are prepared and consumed along with the cooking water, all tests were performed for the mixture noodle + cooking water.

The total calcium of the noodle formulations ranged from 3.78 to $88.47 \mathrm{mg}$ of calcium per $100 \mathrm{~g}$ of sample. The control presented lower total calcium levels when compared with that reported by the Brazilian Food Composition Table (18 mg/100g) (Nepa, 2011), probably due to various factors, including the different cultivar, climatic conditions, and the flour extraction rate (Afridi et al., 2011). In certain countries, such as the United Kingdom, the fortification of ground (white) flour with calcium to restore the calcium levelof whole flour is mandatory (Marcovecchio et al., 2015). The sample preparation for analysis may also have contributed to the divergence of these values. However, the use of alkaline salts in instant noodle formulations led to a significant increase in calcium contents, which can contribute to the intake of this mineral.

When simulating the gastrointestinal digestion through the dialysis assay of the instant noodles, both the control and the formulation N3 exhibited lower dialyzed calcium levels when compared with the quantification limit $(0.25 \mathrm{mg} / 100 \mathrm{~g}) . \mathrm{On}$ the 
other hand, the formulations N2 and N4 presented dialyzed calcium contents of 3.69 and $2.89 \mathrm{mg} / 100 \mathrm{~g}$, respectively.

Table 5. Calcium bioaccessibility of alkaline instant noodle with different combinations of alkaline salts ${ }^{1}$

\begin{tabular}{cccc}
\hline \multirow{2}{*}{ Samples } & \multicolumn{2}{c}{ Calcium content $\mathbf{( m g / 1 0 0 g})$} & \% dialysis \\
\hline N1 & $3.78 \pm 0.37$ & Dialyzed & $*$ \\
N2 & $54.47 \pm 0.13$ & $<0.25$ & $6.78^{\mathrm{a}}$ \\
N3 & $52.92 \pm 0.60$ & $3.69 \pm 0.40$ & $*$ \\
N4 & $88.47 \pm 1.35$ & $<0.25$ & $3.27^{\mathrm{b}}$ \\
\hline
\end{tabular}

${ }^{1}$ Results are presented as mean \pm standard deviations. $\mathrm{N} 1: 0.50 \% \mathrm{~K}_{2} \mathrm{CO}_{3}+0.50 \% \mathrm{Na}_{2} \mathrm{CO}_{3} ; \mathrm{N} 2: 0.50 \% \mathrm{~K}_{2} \mathrm{CO}_{3}+0.50 \% \mathrm{CaCO}_{3} ; \mathrm{N}_{3}: 0.50 \%$ $\mathrm{Na}_{2} \mathrm{CO}_{3}+0.50 \% \mathrm{CaCO}_{3} ; \mathrm{N} 4: 1 \% \mathrm{CaCO}_{3}$. Means followed by different letters on the same line differ significantly from each other by the Scott-Knott test $(\mathrm{p}<0.05)$.

Source: Authors.

It is worth mentioning the impact of the association between calcium carbonate and potassium carbonate, which increased the percentage of dialyzed calcium in N2, even when the amount of calcium added was lower when compared to the formulation $\mathrm{N} 4$.

Higher total and dialyzed calcium contents were expected in the samples due to the calcium source used, calcium carbonate, which presented $51.42 \%$ of dialyzed calcium when analyzed outside the food matrix. However, calcium loss during the pre-cooking and frying steps may have occurred. No data were found in the literature that can be correlated with the present study. Several technological steps are involved in the manufacture of instant noodles, including mixing, cutting, pre-cooking, frying, drying, and packaging. These processing steps as well as the digestive process can lead to complex interactions between minerals and the food matrix components, with positive or negative effects on the bioavailability of nutrients (Marcovecchio et al., 2015).

One hypothesis for the low dialyzed calcium content of the formulations containing sodium carbonate, $\mathrm{N} 1$ and N3, is the presence of a greater amount of sodium ions from the $\mathrm{NaCl}$ added to the formulation, in addition to $\mathrm{Na}_{2} \mathrm{CO}_{3}$. This fact may have contributed to a greater development of the gluten network, with a lower content of dialyzed calcium found in the bioaccessibility assay.

The fat used in the deep fat-frying may have also affected the low bioaccessible calcium levels. In the digestive process, carbohydrates, proteins, and lipids are degraded through specific conditions and enzymes, leading to the formation of new bonds and alteration of existing bonds, thus affecting their affinities with metal ions (Lorieau et al., 2018). It is known that the calcium absorption rate is influenced by the type of fat used during frying, leading to the formation of insoluble, non-absorbable calcium soaps with long-chain fatty acids. Therefore, during the frying process, free calcium tends to bond with the fat and form soap, thus becoming less bioaccessible (Lorieau et al., 2018).

In addition, each calcium compound has a different solubility and is dependent on the $\mathrm{pH}$ of the environment, with maximum solubility generally achieved under acidic conditions. During the digestive process, $\mathrm{pH}$ can change from an acidic environment (gastric digestion) to a neutral environment (enteric digestion) (Lorieau et al., 2018). Studies have shown the total solubility of different calcium salts (glycerophosphate, carbonate, phosphate, citrate, and oxalate) at $\mathrm{pH} 3$. However, in the enteric stage, the calcium solubility decreases with an increase in pH to 7 (Goss et al., 2007; Lorieau et al., 2018). The increase in $\mathrm{pH}$ can lead to the formation of a calcium precipitate with a molecular weight greater than the membrane pore size used for dialysis, which may have reduced the amount of calcium available to cross the semipermeable membrane.

The dialysis method (in vitro) is based on the simulation of gastrointestinal digestion, followed by the quantification of the element of interest, which crosses a semipermeable membrane simulating the intestinal wall, under controlled conditions of 
temperature, agitation, $\mathrm{pH}$, and presence of enzymes. There are no studies on the use of calcium salts in instant pasta and bioaccessibility assessment. Although the simulated gastrointestinal digestion through the dialysis assay does not represent the complexity of the human digestive process, it has been used to estimate the availability of nutrients present in food, correlating with in vivo tests (Hur et al., 2011).

\section{Conclusion}

The present results showed that the instant noodle formulationN2 made with the combination of calcium and potassium carbonates resulted in a quality product suitable for consumption. It presented satisfactory technological characteristics, with a reduction of $28 \%$ sodium when compared with the control, and similar color characteristics to the other formulations. In addition, it presented hydration behavior similar to the control, greater resistance to breakage, and maintenance of alkaline $\mathrm{pH}$ values, characterizing the product as an alkaline instant noodle. Although the formulation N2 presented lower calcium content when compared to N4, it was more bioaccessible, with values 2 to 7 times higher when compared to the other treatments. Thus, the use of calcium carbonate in alkaline instant noodles has proven to be a promising alternative to increase Ca intake and to reduce the sodium levels of the final product.

\section{Acknowledgments}

This study was financed in part by the Coordenação de Aperfeiçoamento de Pessoal de Nível Superior - Brasil (CAPES) - Finance Code 001. The authors also thank the scholarship awarded for the students Priscila Tavares and Guilherme, the Pastificio Selmi for donating the wheat flour, and Imerys do Brasil for donating calcium carbonate.

\section{References}

AACCI. (2010). Approved Methods of Analysis. AACC International.

ABIMAPI. (2020). Associação Brasileira das Indústrias de Biscoitos, Massas Alimentícias e Pães e Bolos Industrializados.

Afridi, H. I., Kazi, T. G., Kazi, N., Kandhro, G. A., Baig, J. A., Shah, A. Q., Khan, S., Kolachi, N. F., Wadhwa, S. K., \& Shah, F. (2011). Evaluation of status of calcium, magnesium, potassium, and sodium levels in biological samples in children of different age groups with normal vision and night blindness. Clinical Laboratory, 57(7-8), 559-574.

Alegría-Torán, A., Barberá-Sáez, R., \& Cilla-Tatay, A. (2015). Bioavailability of minerals in foods. In M. de la G. and S. Garrigues (Ed.), Handbook of Mineral Elements in Food. https://doi.org/doi:10.1002/9781118654316.ch3

Asenstorfer, R. E., Wang, Y., \& Mares, D. J. (2006). Chemical structure of flavonoid compounds in wheat (Triticum aestivum L.) flour that contribute to the yellow colour of Asian alkaline noodles. Journal of Cereal Science, 43(1), 108-119. https://doi.org/10.1016/j.jcs.2005.09.001

Brasil, Ministério da Agricultura, P. e do A. (2000). Regulamentos Técnicos de Identidade e Qualidade de Almôndega, de Apresuntado, de Fiambre, de Hamburguer, de Kibe, de Presunto Cozido e de Presunto. IN 20/2000 (p. 15). Ministério da Agricultura, Pecuária e Abastecimento.

Brasil. (2010). Aditivos Alimentares autorizados para uso segundo as Boas Práticas de Fabricação (BPF). 27.

Cámara, F., Amaro, M. A., Barberá, R., \& Clemente, G. (2005). Bioaccessibility of minerals in school meals: Comparison between dialysis and solubility methods. Food Chemistry, 92(3), 481-489. https://doi.org/10.1016/j.foodchem.2004.08.009

Fu, B. X. (2008). Asian noodles: History, classification, raw materials, and processing. Food Research International, 41(9), 888-902. https://doi.org/10.1016/j.foodres.2007.11.007

Goss, S. L., Lemons, K. A., Kerstetter, J. E., \& Bogner, R. H. (2007). Determination of calcium salt solubility with changes in pH and P CO2 , simulating varying gastrointestinal environments. Journal of Pharmacy and Pharmacology, 59(11), 1485-1492. https://doi.org/10.1211/jpp.59.11.0004

Gropper, S.S; Smith, J.L; Groff, J. L. (2011). Advanced nutrition and human metabolism (5a ed.).

Gulia, N., Dhaka, V., \& Khatkar, B. S. (2014). Instant Noodles: Processing, Quality, and Nutritional Aspects. In Critical Reviews in Food Science and Nutrition. 54(10), 1386-1399. https://doi.org/10.1080/10408398.2011.638227

Gulia, N., \& Khatkar, B. S. (2013). Effect of processing variables on the oil uptake, textural properties and cooking quality of instant fried noodles. Journal of Food Quality, 36(3), 181-189. https://doi.org/10.1111/jfq.12029 
Han, L., Lu, Z., Hao, X., Cheng, Y., \& Li, L. (2012). Impact of calcium hydroxide on the textural properties of buckwheat noodles. Journal of Texture Studies, 43(3), 227-234. https://doi.org/10.1111/j.1745-4603.2011.00331.x

Hobbs, J. E. (2020). Food supply chains during the COVID-19 pandemic. Canadian Journal of Agricultural Economics/Revue Canadienne d'agroeconomie, cjag.12237. https://doi.org/10.1111/cjag.12237

Hoover, E. (2020). Native food systems impacted by COVID. Agriculture and Human Values. https://doi.org/10.1007/s10460-020-10089-7

Hou, G. (2001). Oriental noodles. In Advances in Food and Nutrition Research (Vol. 43, Issue C, pp. 141-193). https://doi.org/10.1016/S1043-4526(01)43004$\mathrm{X}$

Hou, G. G. (2010). Asian Noodles: Science, Technology, and Processing. In G. G. Hou (Ed.), Asian Noodles: Science, Technology, and Processing. John Wiley \& Sons, Inc. https://doi.org/10.1002/9780470634370

Hur, S. J., Lim, B. O., Decker, E. A., \& McClements, D. J. (2011). In vitro human digestion models for food applications. Food Chemistry, 125(1), 1-12. https://doi.org/10.1016/j.foodchem.2010.08.036

Ismailoglu, S. O., \& Basman, A. (2016). Physicochemical properties of infrared heat-moisture treated wheat starch. Starch/Staerke, 68(1-2), 67-75. https://doi.org/10.1002/star.201500160

Kajishima, S., Pumar, M., \& Germani, R. (2003). Efeito de adição de diferentes sais de cálcio nas características da massa e na elaboração de pão francês. Ciência e Tecnologia de Alimentos, 23(2). https://doi.org/10.1590/s0101-20612003000200021

Kruger, J. E., Matsuo, R. B., \& Dick, J. W. (1996). Pasta and Noodle Technology. American Association of Cereal Chemists.

Lorieau, L., Le Roux, L., Gaucheron, F., Ligneul, A., Hazart, E., Dupont, D., \& Floury, J. (2018). Bioaccessibility of four calcium sources in different wheybased dairy matrices assessed by in vitro digestion. Food Chemistry, 245, 454-462. https://doi.org/10.1016/j.foodchem.2017.10.108

Marcovecchio, J. E., De Marco, S. G., Buzzi, N. S., Botté, S. E., Labudia, A. C., La Colla, N., \& Severini, M. D. F. (2015). Fish and seafood. In Handbook of Mineral Elements in Food (pp. 621-643). John Wiley \& Sons, Ltd. https://doi.org/10.1002/9781118654316.ch27

Miller, D. D., Schricker, B. R., Rasmussen, R. R., \& Van Campen, D. (1981). An in vitro method for estimation of iron availability from meals. The American Journal of Clinical Nutrition, 34(10), 2248-2256. https://doi.org/10.1093/ajcn/34.10.2248

NEPA. (2011). Tabela brasileira de composição de alimentos. NEPA - Unicamp, 161. http://www.unicamp.br/nepa/taco/

Nilson, E. A. F., Jaime, P. C., \& De Oliveira Resende, D. (2012). Iniciativas desenvolvidas no Brasil para a redução do teor de sódio em alimentos processados. Revista Panamericana de Salud Publica/Pan American Journal of Public Health, 32(4), 287-292. https://doi.org/10.1590/S1020-49892012001000007

Orlando, E. A., Rebellato, A. P., Silva, J. G. S., Andrade, G. C., \& Pallone, J. A. L. (2020). Sodium in different processed and packaged foods: Method validation and an estimative on the consumption. Food Research International, 129, 108836. https://doi.org/10.1016/j.foodres.2019.108836

Park, J., Lee, J. S., Jang, Y. A., Chung, H. R., \& Kim, J. (2011). A comparison of food and nutrient intake between instant noodle consumers and non-instant noodle consumers in Korean adults. Nutrition Research and Practice, 5(5), 443-449. https://doi.org/10.4162/nrp.2011.5.5.443

Paula, L. N. de. (2013). Enriquecimento do café torrado e moído com sais de cálcio. Universidade Tecnológica Federal do Paraná.

Perales, S., Barberá, R., Lagarda, M. J., \& Farré, R. (2006). Fortification of milk with calcium: Effect on calcium bioavailability and interactions with iron and zinc. Journal of Agricultural and Food Chemistry, 54(13), 4901-4906. https://doi.org/10.1021/jf0601214

Pongpichaiudom, A., \& Songsermpong, S. (2018). Characterization of frying, microwave-drying, infrared-drying, and hot-air drying on protein-enriched, instant noodle microstructure, and qualities. Journal of Food Processing and Preservation, 42(3), e13560. https://doi.org/10.1111/jfpp.13560

Rebellato, A. P., Pacheco, B. C., Prado, J. P., \& Lima Pallone, J. A. (2015). Iron in fortified biscuits: A simple method for its quantification, bioaccessibility study and physicochemical quality. Food Research International, 77, 385-391. https://doi.org/10.1016/j.foodres.2015.09.028

Sahuquillo, A., Barbera, R., \& Farre, R. (2003). Bioaccessibility of calcium, iron and zinc from three legume samples. Nahrung, 47(6), 438-441. https://doi.org/10.1002/food.200390097

Silva, J. G. S., Rebellato, A. P., Caramês, E. T. dos S., Greiner, R., \& Pallone, J. A. L. (2020). In vitro digestion effect on mineral bioaccessibility and antioxidant bioactive compounds of plant-based beverages. Food Research International, 130, 108993. https://doi.org/10.1016/j.foodres.2020.108993

Smith, J., \& Hong-Shum, L. (2011). Gases. In Food Additives Data Book (pp. 581-596). Wiley-Blackwell. https://doi.org/10.1002/9781444397741.ch8

Tan, H. Z., Li, Z. G., \& Tan, B. (2009). Starch noodles: History, classification, materials, processing, structure, nutrition, quality evaluating and improving. In Food Research International (Vol. 42, Issues 5-6, pp. 551-576). https://doi.org/10.1016/j.foodres.2009.02.015

Umbelino, D. C., Rossi, E. A., Cardello, H. M. A. B., \& Lepera, J. S. (2001). Sensory and technological aspects of calcium enrichment of a soy-whey-yogurt. Ciência e Tecnologia de Alimentos, 21(3). https://doi.org/10.1590/S0101-20612001000300005

Wang, H. (2016). Discoloration of dough for oriental noodles. Cereal Chemistry., 93(2), 198-205. https://doi.org/10.1016/B978-012119062-0/50001-2

Wang, L., Hou, G. G., Hsu, Y. H., \& Zhou, L. (2011). Effect of phosphate salts on the Korean non-fried instant noodle quality. Journal of Cereal Science, 54(3), 506-512. https://doi.org/10.1016/j.jcs.2011.09.008

WINA. (2020). World Instant Noodles Association. 
Research, Society and Development, v. 10, n. 2, e51210212778, 2021

(CC BY 4.0) | ISSN 2525-3409 | DOI: http://dx.doi.org/10.33448/rsd-v10i2.12778

Ye, Y., Zhang, Y., Yan, J., Zhang, Y., He, Z., Huang, S., \& Quail, K. J. (2009). Effects of flour extraction rate, added water, and salt on color and texture of Chinese white noodles. Cereal Chemistry, 86(4), 477-485. https://doi.org/10.1094/CCHEM-86-4-0477

Yu, L. J., \& Ngadi, M. O. (2004). Textural and other quality properties of instant fried noodles as affected by some ingredients. Cereal Chemistry, 81(6), 772776. https://doi.org/10.1094/CCHEM.2004.81.6.772 